\title{
The Practice Structured on the Discourse: Repertoires and Dominant Discourses in Brazilian Scientific Literature on Agrochemicals
}

\author{
Larissa Hery Ito Ribeiro Homem ${ }^{1}$, Michelle Bonatti ${ }^{1}$, Luiz Renato D'Agostini ${ }^{1}$, Marcos Lana ${ }^{1} \&$ Stefan Sieber ${ }^{1}$ \\ ${ }^{1}$ Leibniz Centre for Agricultural Landscape Research (ZALF), Germany \\ Correspondence: Larissa Hery Ito Ribeiro Homem, Leibniz Centre for Agricultural Landscape Research (ZALF), \\ Germany. E-mail: lari.ito@gmail.com
}

Received: September 24, 2015 Accepted: October 20, 2015 Online Published: January 29, 2016

doi:10.5539/sar.v5n1p109

URL: http://dx.doi.org/10.5539/sar.v5n1p109

\begin{abstract}
The present work aims to clarify the discursive practices of Brazilian scientific literature on chemical pesticides in order to understand, from a historical perspective, which repertoires are available to give meaning to the use of pesticides in Brazil. It further draws a picture of the positions taken in the technical area, from the creation of the "Agrochemicals Law" in 1989 until the present day. A total of 78 articles from ten journals were reviewed using the analysis of the discourses method as well as an overview of the database according to years, authors, and titles. The results show that scientific production is concentered in the south and southeast Brazilian institutions where the authors mostly come from. Their articles analyze presented repertoires that were categorized into three types: "required use of pesticides", "use of pesticides integrated with biological control", and "no use of pesticides". The results suggest that there is no consensus in the discursive practices of Brazilian scientific literature on agrochemicals. It was concluded that there is in literature the suggestion that integrated pest control could improve the quality of production and lessen impacts on health and the environment. The dominant discourse is still linked to the paradigm that in order to have a high level of food production it is still necessary to use pesticides.
\end{abstract}

Keywords: agrochemicals law, discursive practices, knowledge production, land-use management pesticides, food production

\section{Introduction}

Although agrochemicals were introduced in Brazil at the end of the 1940s, it was only in the 1960s that they became more widely used and accompanied by chemical fertilizers, liming, hybrid and certified seeds, and tractors and other machinery. The introduction of these technologies was the result of the growing rural expansion in the country and the strong material support from the government as well as North American entrepreneurs (Alves Filho, 2002).

Currently, Brazil is the biggest consumer of agrochemicals worldwide and at the same time is considered to be the market with the highest growth potential in the near future. Porto and Soares (2012) summarize the current scenario of the hegemonic Brazilian agrarian model: based on single commodities for export, intensive use of mechanized technologies, and the use of chemical pesticides.

Peres et al. (2003) found that Brazil increased expenditure on these supplies from 1 to 2.2 billion dollars per year between 1964 and 1991 (approximately 120\%). Pesticide consumption increased 276.2\%, while there was a 76\% increase in planted area. Between the years 1970 and 1980, a program aimed at gradually eliminating Brazilian dependence on imports was implemented. This encouraged local production, resulting in a technological leap with the synthesis of various molecules contained in the agrochemicals and the establishment of the PDA (National Plan of Agrochemicals) in 1975 (Porto \& Soares, 2012). According to Kageyama (1985) the modernization of national agriculture was based on the imposition of the use of chemical inputs (among them pesticides) and also biological inputs, and the use of mechanization in the technical and productive base of agriculture. That is, modernization of national agriculture caused a rise in the use of industrial inputs in the production of agricultural products. Agriculture was seen as an industrial consumer market within a general process of industrialization of the Brazilian economy.

Among other measures, the Federal Government invested more than 200 million dollars in chemical industries, 
following the trend in which government incentives were part of a worldwide policy for developing countries (Alves Filho, 2002, Porto \& Soares, 2012). A study by the Food and Agriculture Organization and INTERNATIONAL FERTILIZER INDUSTRY ASSOCIATION (FAO/IFI, 1999) in 38 developing countries showed that 26 of them subsidized fertilizer use.

The government incentives contributed to the indiscriminate use of agrochemicals because of the subsidies and rural extension programs offered. It was used not only by the wealthiest farmers, but also by family producers who were compelled and driven to acquire this "technological packet" in an uncontrolled manner with no regard to technical requirements. This agronomic prescription and the agricultural practices exposed farmers and rural workers to health risks related to the use of agrochemicals (Porto \& Soares, 2012). Peres and Rozemberg (2003) suggest that the discourse and practices in the field justify the use of pesticides as being necessary for a 'productive agriculture': they are the only solution for the problem of world hunger, since the population is growing exponentially while the amount of land available for food production is decreasing drastically. The authors point out that this discourse is common to agronomists and other professionals linked to industrial agriculture, and even some linked to the government, and that it has a very clear origin: the interest of major chemical and pesticide industries.

Therefore, there is a network of social actors that maintains this problematic situation in Brazil. Researchers and universities also share a responsibility, as they come under the category of social actors who represent scientific knowledge, which is that they should highlight this complex situation and analyze the implications and potential benefits and damage with the use of chemical pesticides.

Menegon (1998) points out that the knowledge that circulates through society has been fed with, and at the same time is feeding, the various domains of knowledge. In this sense, scientific literature can be considered as a form of social discourse. These discursive practices are linguistic repertoires that contribute to producing social meanings and also to the formation, maintenance and the diffusion of some problematic situations (Menegon, 1998).

Looking at the broad use and distribution of pesticides in agricultural production areas as a complex and problematic situation, the search for linguistic repertoires on pesticides/agrochemicals in scientific production in Brazil is necessary to understand its process as a social construct. Michel Foucault (1972 and 1973) explicitly addresses the problem of statement production, and relates this question with the production of events at the intersection of different forces or social trends. Thus the main objective of this study is to contribute to clarify which linguistic repertoires form the discursive practices transmitted by the scientific production of agrochemicals in Brazil, and how they composes the dominant discourse in agricultural scientific publications.

\subsection{The Use of Agrochemicals and the Social Actors in Brazil}

Despite the concept that agrochemicals are a modern technology in the control or elimination of issues arising from pests and diseases in plants and animals, the use of toxic substances can be found in records dating back to Classical Antiquity. However, the spread and increasing use of synthesized biocides occurred after the Second World War with the development of the chemical synthesis industry (Alves Filho, 2002). Only at the end of the1950s and the beginning of the1960s did the first processes for re-evaluating issues involving the safety and efficiency of agrochemicals arise in the international technical community, largely led by the publication of the book Silent Spring by Rachel Carson in 1962. The consistent arguments put forward by Carson mobilized American opinion and led to the creation of the Environmental Protection Agency(EPA).After this, organochlorides were banned and from 1971 various synthetic products were also banned or their use was restricted by the EPA due to their harmful effects on health and the environment (Alves Filho, 2002).

In Brazil, government and chemical industries play a major role in the dissemination of agrochemicals. According to Lutzemberg (1985) the chemical industry managed to impose its paradigm on agricultural research and promotion. This indicates the centrality of this social actor, which in Brazil is represented by ANDEF (National Association of Plant Protection). However, Waichman (2012, p. 44) points out that: "it would be naïve to put all the responsibility on the industries that produce the agrochemicals for the damage caused by them, since the farmers and society, in a broader sense, are also responsible". The author thus draws attention to the wide range of social actors who participate in the spread of agrochemicals, such as rural extension workers who have historically been related to the spread of pesticide use in agricultural production in Brazil.

According to Waichman, (2012, p. 44): "Based on the principle of promoting agricultural modernization in the country, rural extension was largely responsible for implementing technological packets based on the adoption of agrochemicals (...)". 
Another social actor who can be considered as a central figure in the pesticide use chain is the consumer. We can consider food consumption as part of a wider chain that goes from planting to the distribution and consumption of food. The "consumers" category of social actor especially widens the idea of implication in or responsibility for the problem, since we all fit into the "food consumer" category. Consumers select what kind of product to consume, and thus support the entire production process.

In the case of collective reach, it is also important to mention a milestone in the country: the creation of Law 7.892, known as the Agrochemicals (Note 1) Law, enacted in 1989; which, despite criticism of its effectiveness, represents an important advance for environmental movements. According to Pelaez, Silva and Araújo (2013), this advance should be seen in the context of parliamentary mobilization for environmental preservation at the1988 Constituent Assembly, as well as the creation of state laws to control agrochemicals in support of environmental movements organized in some states of the federation. Law 7.892, replacing Decree 24.114 of 1934, was approved by the National Congress.

Law 7.892 provides for research, experimentation, production, packaging and labeling, transportation, storage, selling, advertising, use, import and export, final destination for wastes and packaging, registration, classification, control, and inspection of agrochemicals and their behavior. Among the advances and limitations of the Law, the designation of the term "Pesticide" as appropriate to denote such chemical simplies the recognition of the related toxicity and represents a new conception of this questionon the part of the State. Up to the Constitution of 1988 (published in 1989), Brazilian legislation referred to this group of chemical products as "crop protection products", a name which, by its very meaning, excluded all agents used in urban health campaigns (Peres, Moreira, \& Dubois, 2003).

\subsection{Linguistic Repertoires and Positioning on the Use of Agrochemicals}

The denomination "agrochemicals" has spread widely throughout Latin America as part of the environmental protection movement. More than just a mere change in name, this term aims to bring to light the toxicity of these products in relation to the environment and human health.

As observed by Garcia Cardona (2008), none of the terms used escape the connotations that accompany them: "the terms themselves 'speak' of their origins and identify their authors" (p.10). The terms and language in the broadest form, in their varied manifestations, are considered a practice - a form of action in the world, and as such, they affect the social structure. They are part of the constructions, maintenance and changes that underlie social relations over the years; an instrument for creating events and a condition of existence for certain social structures and problematic situations (Méllo et al., 2007).

Thus, the comprehension of terms and language as generators of meaning, with all its centrality in the social construction of knowledge, has become a focus of interest for authors who aim to understand the power of discourse in varied fields of knowledge, originating from "discourse analysis"(Méllo et al., 2007).

Spink and Medrano (1999) define discursive practices as language in action, in other words, ways in which people produce meanings. Moreover, as it relies on discursive language practices in action, there are consequences which are not always intentional in argumentation: "when we speak we are invariably performing actions: accusing, asking, justifying, etc. - playing a game of positioning with our counterparts, whether intentional or not" (Spink \& Medrado, 1999, p. 47).

Discursive practices are a central component of language and they are made up of repertoires (Wetherell \& Potter, 1987; Spink, 2010). For Wetherell (1998) the repertoires are "sets of terms, descriptions, common places and language figures that are frequently grouped around metaphors and images, using their own grammatical constructions and styles" (Wetherell, 1998).

Linguistic repertoires are found in a variety of linguistic productions from the learning process within the linguistic community in which people were socialized. For Spink (2010) we live with a wide variety of linguistic content and uses: in a single day, we are faced with a variety of repertoires about the concepts of children, about marriage or menopause, which are distinct and are derived of diverse historical periods or distinct social situations. Thus, when working with repertoires, it is worth mentioning is that they have a long history (Spink, 2010; Menegon, 2008).

The repertoires enable us to access polysemy, which characterizes discourse and means "the different meanings of the same word in a determined period". Thus, we have access to both the stability and the variability of human linguistic production. Besides regularities and consensus, it is possible to follow the line of argument used to present or defend an idea, which, instead of being consistent, also includes contradictions and a continuous negotiation of meanings. Admitting that the discursive practices are polysemic does not, however, imply that 
there is no tendency towards hegemony (Spink \& Medrado, 1999, p. 48).

Science was one of the main amalgams of the modern era and despite the growing demystification of its objectivity in postmodern reflections it is still an important locus for the generation of meanings. For Mirim (1999), discursive discussions in the scientific domain contribute to the formation and diffusion of varied interpretive repertoires that constantly reconstruct and generate new meanings in society. The scientific discourses are marked by social languages that focus on the discursive formations from previous eras. The analysis of repertoires in scientific productions enables us to question the rhetoric of modern science that often sees it self as the last retainer of knowledge that will serve those interested in improving various problematic situations.

Therefore, with regard to the wide use of agrochemicals in Brazilian agricultural production and the role of scientific language in establishing social relations, the focus of this study is to understand the ways by which the language used in the Brazilian scientific discourse deals with the use of agrochemicals.

The importance of the study and the conclusions to the advancement of scientific knowledge are related to the understanding of how the problematic situation of pesticide use in Brazil is socially structured. As postmodern science approaches have shown, inevitably, the participants are non-neutral in the construction of knowledge. Science as a retainer of knowledge should be questioned in view of the socio-historical construction of facts and events, as evidenced by the fact that different eras produce different versions of them.

\section{Research Methods}

This study adopted a theoretical-methodological approach for analyzing discursive practices. On the source of data and variables used, this study included a survey of scientific documents (articles) from the open database Scielo.org, which contains a vast number of publications from Latin America and the Caribbean. The focus was on Brazilian scientific production in the rural area. Due to the huge number of different names for agrochemicals, the blanket term "pesticides" was chosen as the key word in this study considering that the term is widely used in the English language, and in the chosen data base most of the studies contain a version of the title and abstract in English. The database search consisted of:

Key word =pesticides,

In method = integrated, and the

Region $=$ Brazil

Thus, 486 articles were obtained from periodicals from various areas. From then on, some criteria of interest were utilized to define the final sample. The criteria for selection of periodicals were:

- Provide technical character studies of rural or agricultural area (eliminating those more sociological, for example);

- Publications of year 1989 (due Pesticides Law) by 2012;

- Journal that present more than 05 publications according to our search criteria above mentioned. This last criterion is related was the annual frequency of scientific production in the study area. Then only those which showed at least five publications per year were retained. A total of 78 articles from 10 journals were selected. The next criterion was that the summary had to contain the term "pesticides". The last criterion was the time frame, publications from 1989 to 2012, from the enactment of the Pesticides Law up to the present day.

The results analysis strategy has four steps: The first two steps related to the general assessment of set of publications, adjusted from the method of study-data processing by Mirim (1999). The other two items about the analysis of the repertoires and discourses, adapted from Moreira (2009) and Moreira e Rasera (2010):

a) Description of the number of journals and articles by date, study of the nuclei of titles. At this stage, the aim was to seek a broader overview of publications on agrochemicals, the variety, contradictions, and consistencies in the use of terms.

b) Mapping the origin of the authors related to the publications topics. Situating authors and institutions of the articles was conceived to trace the rural scientific production on agrochemicals in Brazil.

c) Analysis of the discourse of the articles to find texts that search for a pattern in the repertoires and positioning about agrochemicals use.

d) Summary of dominant discourse(s) present in the scientific production selected for this study.

The discourse analysis (stage c), was carried out through the "Codification and Analysis" process described by 
Moreira (2009) and Moreira and Rasera (2010). Codification is reading in search of details, contradictions, nuances, and passages of discourse. In other words, it is a procedure for identifying categories, emphasizing topics of interest in the broadest way possible, in such a way so that all the neighboring instances may be included, instead of being left out.

Analysis can be divided into two related stages. First, there is a demand for a standard in data, which shows both in the variability - in the difference between the narrations - and the consistency. The function is then investigated in order to generate hypotheses on the functions of the discourse.

The question guiding the results analysis survey was: What are the main repertoires and dominant discourses in Brazilian Scientific literature from the rural area.

\section{Results and Discussion}

A final sample resulted in 78 relevant articles based on the selection criteria outlined above. Given the complexity and volume of the data, the results given below were grouped into four different sections: Publication database analysis, General Panorama, Synthesis of repertoires and Dominant Discourses.

\subsection{Publication Database Analysis}

Only articles from 1993 onwards were found, although the selection began in 1989. The number of publications per year was inconsistent, with increases followed by years of few productions.

Regarding the description of the items from the design of the titles of articles and cores: The term "agrochemical" occurred more frequently in the titles $(\mathrm{n}=19)$. However, even in this case the term was not used exclusively in the text. "Phytosanitary products" $(\mathrm{n}=8)$ was a recurring word as well as the terms "Insecticides" $(n=7)$, "Miticides" $(n=5)$ and "Herbicides" $(n=5)$, which in most cases appeared together.

The mapping of the authors presents the fact that authors from different areas and institutions frequently co-author articles. The data about the authors are quite varied, and do not have a pattern of information about institutions of origin and area of study.

The majority of authors come from academic institutions. The Federal University of Lavras (UFLA) in Midwest of country, was the most referenced, followed by State University of São Paulo (UNESP, and the University of São Paulo (USP), southwest, followed by EMBRAPA, a Federal institution, and a small minority from private companies. From the articles analyzed, the authors' predominant area of expertise was phytosanitation, followed by entomology. The mid-western and southeastern regions of Brazil are hegemonic regarding the origin of the authors of the selected articles.

\subsection{Panorama}

Tracing an overview of the results shows that despite the Agrochemicals Law (1989), which set the appropriate terms for the designation of such products, the scientific literature uses various terms to do so.

Despite the high frequency of the term "agrochemicals", various other names were used for agrochemicals throughout the titles and texts analyzed. There was no exclusivity in naming, which is evidence that idea of pesticides as products with the specific function of ensuring the defense of vegetables remains, without referencing their toxicity as a means for this, or them even being necessarily associated with toxicity. As an example, the term "phytosanitary products", which comes from "sanitary", alludes to the conservation or restoration of health and/or relates to hygiene; destined to rid or preserve the public or private health from all that may be harmful, mainly in relation to endemic or contagious diseases. However, the use of the term "phytosanitary" appears in the sense of sanitary measures adopted to protect plants, without a direct connection to human health. The terms insecticide, fungicide and herbicide infer the function of eliminating insects, fungi, and weeds, in the sense of control over the toxicity of products. Thus, the term "chemical control" is vague, considering the recognized lack of both control and knowledge of the risks for the environment and living beings in general through the use of toxic substances for agricultural production.

Regarding the discourses, the results presented here show that the dominant discourse is maintenance of pesticide use, recommended as part of the integrated use of biological control as a tool. Biological control was also included under other focuses such as studies on insect fauna and so-called $3^{\text {rd }}$ generation agrochemicals, which were designed to be less toxic products. Although molecular biology and genetic engineering are the latest trends in the development of agrochemicals, there was no mention of them in the studies analyzed. Furthermore, there was barely a mention of the risk of using agrochemicals.

In this way the panorama of the results reveals a lack of discussions that include studies on risks, such as those developed by Ulrick Beck (2006) and Giddens (1992) that address a "Risk Society" as a model of 
post-modernism. Risk is a word of secondary importance and rarely present in repertoires, and when it is mentioned it is in the sense of "excessive use of agrochemicals cause risk to the environment and human health", or "agricultural work involves potential risks and damage to the health of workers", for example.

\subsection{Synthesis of Repertoires}

The 9 topics, shown in Figure 1, were identified and grouped into 3 types of repertoires: "Necessary use of agrochemicals"; "Integrated use of agrochemicals" and "No use of agrochemicals" (Figure 1). In addition to the synthesis of each repertoire, the terms themselves found in the studies and complete passages in which these repertoires appear were selected and related to each repertoire.

9 recurring Topics

- Persistency

- Toxicity

- Application technology

- Technological alternatives to the use of agrochemicals

- Integrated management

- Application and dynamic of agrochemicals

- Agrochemicals monitoring/evaluation of residues and contamination

- Decontamination techniques

Figure 1. The 03 types of repertoires and the corresponding topics

\section{3 types of recurring repertoires}

\section{- Necessary use of agrochemicals}

- Integrated use of agrochemicals

- No use of agrochemicals

Based on the data analysis, the repertoire "Necessary use of agrochemicals" is typically used by authors/articles to argue for the need to use agrochemicals to ensure productivity and maintain the quality of cultivation and, furthermore, to meet the so-called Best Practices for Agriculture as well as other recommendations from the Ministry of Agriculture. These studies argue strongly that agrochemicals are necessary to ensure sufficient food production for the growing population: The studies in the "Necessary use of agrochemicals" category also cover the importance of reducing the use of agrochemicals in view of the costs and impacts generated. Repertoires here are related to: "residue monitoring", "physico-chemical behavior of agrochemicals," and "reduction in use of agrochemicals." Another point present in those articles related to this type of repertoire, "pesticide use", was the focus on technical/technological and economic significance related to improving the safety and efficacy of pesticide application methods and remediation techniques for decontaminating soil. The authors also warn of inadequate management and the consequences for the environment and health. In the repertoire "integrated use of agrochemicals" and biological control, was verified that favorable climatic conditions for pests (insects, disease and weeds) resulted in low production yields, thus promoting intense use of agrochemicals and causing a number of problems such as chemical resistance in pests and the elimination of natural enemies. This description of pesticide use is associated with a new, more efficient, more economic option, and one with less impact than the conventional use of agrochemicals.

One of the indications is the demand from the international market, which involves giving value to the qualitative aspect and respect for the environment in relation to agricultural produce. In this repertoire, integrated management appears as efficiently enabling product differentiation, thus facilitating its sale and ensuring consumer fidelity due to greater control and guaranteed food safety, respect for the environment, and compliance with social requirements. There are references to the lack of evaluative work on the effects of persistently applying agrochemicals to a specific cultivation for specific natural predators.

In the repertoire, "no use of agrochemicals "appears as a feasible alternative for the use of agrochemicals. Organic cultivations, botanical extracts, bio-fertilizers and biological control are cited as alternatives. In short, the authors highlight the impacts of agrochemicals and the advantages of replacing agrochemicals with organic 
and naturally occurring products. It also describes the technical and economic possibilities for the conversion period of conventional management to organic production.

\subsection{Dominant Discourses}

The discourse on the increase of pests and diseases which should be controlled to ensure agricultural production productivity is predominant among the studies.

In detriment to other spheres, the economic spheres related to ensuring productivity and the introduction to export markets were the strongest justifications in the repertoires of the "necessary use of agrochemicals" and the "integrated use of agrochemicals". Implications for the environment were also cited as contaminating the soil, water resources and, briefly mentioned, the "human health" aspect, without further insights into systemic relations. These discourses advocate that safer and more efficient products are continually being developed and that equipment must be improved to ensure precision in application in order to reduce production costs, such as waterproof clothing or more effective sprays for the purpose of reducing toxic exposure.

This includes considerations of the implications referring to the high potential environmental contamination of such products and their toxicity to humans. Among the environmental implications are: the imbalance in beneficial insect fauna, the population explosion of pests, and consequently, additional applications to control secondary pests. Although uncertainties remain about the environmental performance of agrochemicals, the large number of active agents, and the lack of a methodology to evaluate them, it is believed that the safe use of agrochemicals can be achieved through the environmental study of the behavior of these agrochemicals.

The dominant discourse blames farmers for inappropriate management of agrochemicals. Furthermore, the academic discourse sometimes indicates the inability of farmers to cease chemical control of pests. However, the need for a new approach on the part of the producer is indicated, in which safe agrochemicals must be prioritized at the time of deciding which product to spray. The argument put forward is that farmers are reluctant to reduce the use of agrochemicals because of the risk to investments made in their production. They therefore continue relying on technological packages, including the systematic application of chemical products. The question of the health and safety of the rural worker in the articles analyzed assumes a secondary role.

Consumers were shown as the targets of products with fewer agrochemicals, with the aim of establishing a relationship of trust with the consumer in view of the increased demand for vegetables without chemical waste and which was also environmentally friendly. Technical assistance only received a slight mention, not being considered a significant social actor in the discourses on the use of the agrochemicals analyzed in this literature research. Various social actors, however, were not mentioned.

The "no use of agrochemicals" category points out the chemical control methods as causing an imbalance to the environment as well as polluting it more and more, with the appearance of more resistant insect populations, besides causing serious poisoning to rural workers. The disadvantages of non-use included the low persistence of natural products, their inefficiency as pesticides, and the lack of both technical qualification and scientific studies.

The economic sphere is also an issue talked about in the repertoire of non-use of agrochemicals, including the feasibility and economic-commercial advantages of these products, as well as the opening of new and more consistent markets for produced and processed agricultural products. Positive attributes that enter the discourse include that the produce is healthier, a criterion not based on the satisfaction of the non-toxic product supplier. The social actors appear more participatory in relation to the non-use of agrochemicals in addition to increased environmental awareness, knowledge of political, economic, and social aspectsacquired through participation in courses, lectures, conferences, field days, and training.

\section{Conclusion}

It can be said that the discursive practices around the production of rural expertise primarily support the use of pesticides. This is then the dominant discourse.

The focus is on maintenance aspects consistent with the conventional technological model, even together with other pest control techniques, as biological control. In addition to the justifications to the use of agrochemicals, as weather conditions conducive to the establishment of pests and international importance given the appearance and quality of the fruit, this favorably type of use of pesticides discourse also shows the toxicity of pesticides as naturalized, inherent to the products, and necessarily have to be used in agricultural production.

In this way this study debates have exposed the material elements provided by Science in Brazil to give sense and justified the use of agrochemicals to the currently society. Note that other repertoires were also found in this 
study, and the category "no pesticide use" may indicate the movement and dynamism in which the discursive practices are developed over time. The discursive practices are not static, but are being constructed and reconstructed as action in the world. The risks and concerns related to the human toxicity and systemic impacts on the environment are repertoires in a secondary discourse of currently scientific literature that may be increased by other sources of knowledge, such mass media for instance, or still from other areas of science knowledge, creating new available repertoires in a feedback circuit.

Repertoires thus allow access to polissemic characterizing the speech, ie, the different meanings of a single word, and thus access to stable and dynamic variability of productions of human language. Besides regularities and consensus, they make it possible to follow the line of argument used to bring or defend an idea that shows consistent and contradictions involving an ongoing process of negotiation of meaning. In addition, the range between discourses points to the power relations that permeate the discourses and their production conditions. Thus, the study of discursive practices is not limited to words and phrases, or the meanings they have.

Under the light of Foucault's perspective, there is no reason to deal with hidden meanings, but rather to question as a discourse works, which made it possible, reverberating effects. In this way all "discursive practice" shall be understood as a historical, localized event which carries a: "set of anonymous, historical rules which are always determined by the time and space that have defined the conditions of exercising the statement function in any given epoch, and for a given social, economic, geographic or linguistic area" (FOUCAULT, 1969, p.198). To Foucault the analysis should starting with the discourse itself, from its apparition and its regularity, examine its external conditions of possibility, examine that which motivates the random series of these occurrences and that fixes the limits" Thus there is no truth or speeches that are not linked to various conditions (statements, positions, institutions ...) that make them work. For Davies and Harre (1990), the speeches can create versions of reality that are distinct and incompatible and therefore "to know something is to know in terms of one or more discourses."

In that way, in this study central social issues were mentioned, such as the role of the actors involved in agrochemical use chain. Many are the actors involved but the problematization occurs mainly over the farmers. in the present work, we have historically recreated the motivations for the use of pesticides, their implications, and also social movements and social actors involved, opponents and favorable to the use of it.

Specifically, it was brought to light the discursive practices of the Brazilian scientific literature and repertoire that are available to make sense of pesticide use in Brazil and sketch a picture of the positions taken by researchers at the national scenario. The historicity in the construction of knowledge is constituted as a way to question the objectivity of knowledge, considering that it is set in the history of its production, traditions and ways of life. All ideas are configured in a tangle of versions built collectively, which may allow a relativistic attitude. As pointed out by Spink (1999), this does not suggest living in a world without - "truths", only that it is necessary to believe that they are versions: always specific, negotiated, constructed and adapted to the purposes referred to collectively as relevant.

\section{References}

Alves Filho, J. P. (2002). Uso de agrotóxicos no Brasil: controle social e interessecorporativo. São Paulo, SP: Annablume.

Beck, U. (2006). Living In The World Risk Society. British Journal of Sociology Centennial Professor. London School of Economics and Political Science.

Davies, B., \& Harré, R. (1990). Positioning: The discursive production of selves. Journal for the theory of social behaviour, 20(1), 43-63. http://dx.doi.org/10.1111/j.1468-5914.199

Giddens, A. (1992). From Industrial Society to the Risk Society: Questions of Survival, Social Structure and Ecological Enlightenment. In Theory Culture Society. Sage Publications.

Foucault, M. (1969). La arqueología del saber. Madrid: Siglo XXI.

Foucault, M. (1972). Theatrum philosophicum. Barcelona: Anagrama.

Foucault, M. (1973). El orden del discurso. Barcelona: Tusquets.

Food and Agriculture Organization; International Fertilizer Industry Association. (1999). Fertilizer Strategies. Rome and Paris. Retrieved from ftp://ftp.fao.org/agl/agll /ch10/ch104.pdf

García Cardona, M. C. (2004). Linguagem dos riscos e sujeitos posicionados: o uso de agrotóxicos no Vale de Quíbor, Venezuela. PhD Thesis, Pontifícia Universidade Católica de São Paulo, São Paulo, SP). Retrieved from http://bibmed.ucla.edu.ve 
Kageyama, A. A. (1985). Modernization, productivity and employment in agriculture: a regional. $\mathrm{PhD}$ Thesis. Institute of Economics of the University of Campinas, Campinas, Sao Paulo, Brazil.

Mello, R. P. (2007). Construcionismo, práticas discursivas e possibilidades de pesquisa em psicologia social. Psicologia \& Sociedade, 19(3). http://dx.doi.org/10.1590/S0102-71822007000300005

Menegon, V. M. (1998). Menopausa: imaginário social e conversas do cotidiano. (Master'sthesis, Pontifícia Universidade Católica - São Paulo, Brazil).

Mirin, L. Y. L. (1999). Garimpando sentidos em bases de dados. In M. J. Spink (org.). Prácticas discursivas e produção de sentidos no cotidiano. Pontificia Univeridad Catolica Católica de São Paulo.

Moreira, R. L. C. de A. (2009). Maternidades: os repertórios interpretativos utilizados para descrevê-las. 2009. (Master'sthesis). Federal UniversityofUberlândia, Brazil.

Moreira, R. L. C De., \& Rasera, E. (2010). Maternidades: os repertórios interpretativos utilizados para descrevê-las. Psicol. Soc., 22(3), 529-537. http://dx.doi.org/10.1590/S0102-71822010000300013

Pelaez, V., Da Silva, L. R., \& Araújo, E. B. (2013). Regulationofpesticides: A comparative analysis. Science and Public Policy (Online), 1, 1-13. http://dx.doi.org/10.1093/scipol/sct020

Peres, F., Moreira, J. C., \& Dubois, G. S. (2003). Agrotóxicos, saúde e ambiente: uma introdução ao tema. In Frederico Peres; Josino Costa Moreira. (Org.). É veneno ou é remédio? Agrotóxicos, saúde e ambiente (1st ed., vol. 1, pp. 21-41), Rio de Janeiro: Editora da Fiocruz.

Peres, F., \& Rozemberg, B. (2003). É veneno ou é remédio? Os desafios da comunicação rural sobre agrotóxicos. In Frederico Peres; Josino Costa Moreira. (Org.). É veneno ou é remédio? Agrotóxicos, saúde e ambiente, (1st ed., vol. 1, pp. 327-346), Rio de Janeiro: Editora da Fiocruz.

Porto, M. F., \& Soares, W. L. (2012). Modelo de desenvolvimento, agrotóxicos e saúde: um panorama da realidade agrícola brasileira e propostas para uma agenda de pesquisa inovadora. Rev. Bras. Saúde Ocup., São Paulo, v. 37, n. 125, June. http://dx.doi.org/10.1590/S0303-76572012000100004

Potter, J., \& Wetherell, M. (1987). Discourse and social psychology: Beyond attitudes and behaviour. Sage.

Potter, J., Wetherell, M., Gill, R., \& Edwards, D. (1990). Discourse: noun, verb or social practice? Philosophical Psychology, 3(2-3), 205-217. http://dx.doi.org/10.1080/09515089008572999

SPINK, M. J. P., \& MEDRADO, B. (1999). Produção de sentidosno cotidiano: uma abordagem teórico-metodológica para análise das Práticas Discursivas. In Mary Jane Spink. (Org.). Práticas Discursivase Produção de Sentidos no Cotidiano: Aproximações Teórias e Metodológicas (1st ed., vol. 1, pp. 41-61). São Paulo: Cortez.

Spink, M. J. P., \& Frezza, R. M. (1999). Práticas Discursivas e Produção de Sentidos: a Perspectiva da Psicologia Social. In Mary Jane Spink (Org.). Práticas Discursivas e Produção de Sentidos no Cotidiano: Aproximações Teóricas e Metodológicas (1st ed. vol. 1, pp. 17-39), São Paulo: Cortez,.

Waichman, A. V. (2012). A problemática do uso de agrotóxicos no Brasil: a necessidade de construção de uma visão compartilhada por todos os atores sociais. Rev. bras. saúde ocup,São Paulo, v. 37, n. 125, Jun. http://dx.doi.org/10.1590/S0303-76572012000100007

Wetherell, M. (1998). Positioning and interpretative repertoires: Conversation analysis and poststructuralism in dialogue. Discourse and Society, 9(3), 387-412. http://dx.doi.org/10.1177/0957926598009003005

\section{Notes}

Note 1. In Portuguese the specific word adopted by the Law is "Agrotóxicos". In English there is not a literal translation to this term, and for this reason the authors choose to use the approximate term "Agrochemicals" in the present paper.

\section{Copyrights}

Copyright for this article is retained by the author(s), with first publication rights granted to the journal.

This is an open-access article distributed under the terms and conditions of the Creative Commons Attribution license (http://creativecommons.org/licenses/by/3.0/). 